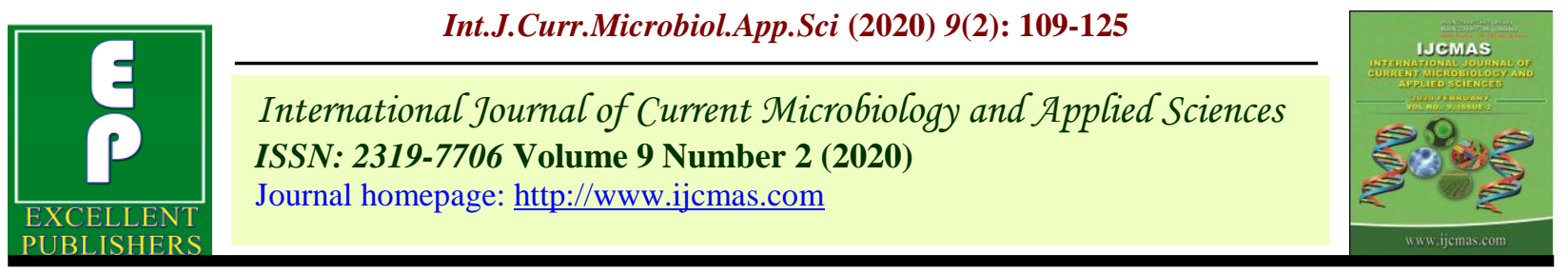

Review Article

https://doi.org/10.20546/ijcmas.2020.902.014

\title{
An Overview of Morphological and Molecular Screening of Antifungal Genes against Northern Corn Leaf Blight (Exserohilum turcicum) from Maize Genotypes-A Review
}

\author{
N. Nagesha* and D. P. Adarsh \\ Department of Plant Biotechnology, College of Agriculture, University of Agricultural \\ Sciences, GKVK, Bengaluru - 560 065, India \\ *Corresponding author
}

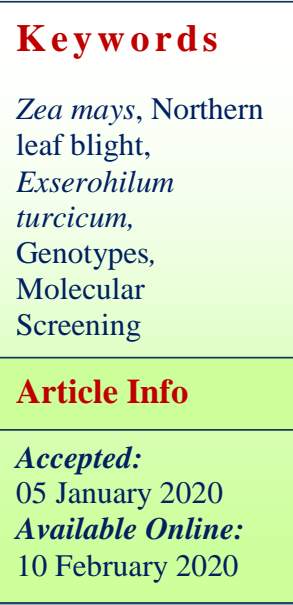

\section{Introduction}

The global food demand is increasing at a rapid rate and the world population is expected reach 9 billion by 2050 and 50 per cent of the arable land is predicted to be deteriorated due to drought and salinity by 2050 (Fig 1). Thus, in order meet the food requirement the production must be increased by at least 35 per cent annually (Shelden and Roessner, 2013). Maize (Zea mays L.) one of the third most important food crop in the world having greater global importance for food, fodder, and fuel. The global food demand and food production is constantly unbalanced. Production wise maize has 
significant figures globally and is often referred to as "Queen of Cereals" due to its wider adaptability and production. The global maize production was around 1040 million MT in the year 2017. The USA contributes 38 per cent of maize production followed by China and Brazil with 23 per cent and 9 per cent respectively. India contributes 2 per cent of global maize production.

Global productivity of maize is estimated to be around $5.6 \mathrm{t} / \mathrm{ha}$. The USA tops productivity followed by Canada and Ukraine (Anonymous, 2017). In the year 2017, the area occupied by maize in India was 9.47 million hectares with a production of 28.72 million MT and productivity of $3.03 \mathrm{t} / \mathrm{ha}$ (IIMR \{Indian Institute of Maize Research\}, 2018). International Grain Council's World and Indian Corn Projections was depicted in Table 1 and 2. In terms of land, Maize is the fifth largest crop in India, and it stands fourth position in terms of production. In India, Karnataka is the largest producer of maize. It produces around 16 per cent of total maize in the country followed by Telangana and Bihar. Haveri, Davangere, Belgaum, Shimoga, and Gadag are major maize producing districts of Karnataka (Ananymous, 2017).

Unsurprisingly, abiotic and biotic stresses are common in maize belts worldwide. Abiotic stresses such as drought, salinity, high and low temperatures, and nutrient deficiency, are primary environmental factors that negatively affect maize production. Recent intense droughts, water logging, and extreme temperatures have severely affected maize growth and yield (Ahuja et al., 2010). In China, 60 per cent of the maize planting area is prone to drought, and the resultant yield loss is 20-30 per cent per year; in India, 2530 per cent of the maize yield is lost as a result of water logging each year (Zaidi et al., 2010). Increasing drought and extreme rainfall are major threats to maize production.
Drought and excessive rainfall ranked, among extreme events, as the first and second largest cause of maize production loss in the United States, totalling damage of 18 and 10 billion US dollars, respectively, from 1989 to 2016. Compared to drought impact, the impact of excessive rainfall on crop yield remains unresolved excessive rainfall can reduce maize yield up to -34 per cent $(-17 \pm 3$ per cent on average) in the United States relative to the expected yield from the long-term trend, comparable to the up to -37 per cent loss by extreme drought $(-32 \pm 2$ per cent on average) from 1981 to 2016 (Li et al., 2019). Drought consistently decreases maize yield due to water deficiency and concurrent heat, with greater yield loss for rainfed maize in wetter areas. Excessive rainfall can have either negative or positive impact on crop yield, and its sign varies regionally. Excessive rainfall decreases maize yield significantly in cooler areas in conjunction with poorly drained soils, and such yield loss gets exacerbated under the condition of high preseason soil water storage. Current process based crop models cannot capture the yield loss from excessive rainfall and overestimate yield under wet conditions. Our results highlight the need for improved understanding and modelling of the excessive rainfall impact on crop yield.

The biotic stresses on maize are primarily pathogens (fungal, bacterial, and viral), and the resultant syndromes, such as ear/stalk rot, rough dwarf disease, and northern leaf blight, are prevalent and cause heavy damage. Initially, diseases in maize were confined to the places of origin but due to the invading nature of the pathogen, they started infesting the maize fields everywhere Approximately 10 per cent of the global maize yield is lost each year as a result of biotic stresses. For example, the European corn borer [ECB, Ostrinia nubilalis (Hubner)] causes yield losses of up to 2000 million dollars annually 
in the USA alone (Basu et al., 2010); in the northern regions of China, the maize yield loss reaches 50 per cent during years when maize is plagued by northern leaf blight ( $\mathrm{Ji}$ et al., 2010). In addition, abiotic and biotic stresses often are present simultaneously and severely influence maize production.

An example of such diseases in maize is maize rusts (Puccinia sorghi) which was endemic to North America today is a common disease around the world. There are about 61 diseases recorded in maize affecting its yield. Of which, 15 diseases and one nematode is considered as major diseases. The major diseases include Turcicum leaf blight (Exserohilum turcicum), Maydis leaf blight (Cochliobolus heterostrophus), Common rust (Puccinia sorghi), Phaeosphaeria leaf spot (Phaeosphaeria maydis), Chrysanthemi stalk rot (Erwinia chrysanthemi p.v. zeae), Pythium stalk rot (Pythium aphanidermatum), Fusarium wilt and stalk rot (Fusarium moniliforme), late wilt (Cephalosporium maydis), charcoal rot (Macrophomina phaseolina), brown stripe downy mildew (Sclerophthora rayssiae var. zeae), Philippine downy mildew (Perenosclerospora philippinensis), sorghum downy mildew ( $P$. sorghi), sugarcane downy mildew $(P$. sacchari), brown spot (Physoderma maydis), banded leaf and sheath blight (Thanatephorus sasakii) and cyst nematode (Heterodera zeae). The first major epidemics in turcicum leaf blight appeared in 1974 on hybrids like Ganga 5, Deccan, PioX104, X114, and Kisan (Payak et al., 1983).

\section{Major fungal diseases in maize}

There are sixty-one maize diseases recorded till now which limited its production. The major diseases include four foliar diseases, two pre-flowering diseases, three posts flowering disease, four downy mildew, and two sheath diseases. One of the major biotic stress diseases causing agent viz., fungal pathogens poses threat to the yield of corn constantly at various stages of their growth and development. A recent estimate shows that loss in economic product per annum is about 13.2 per cent in maize including all the diseases.

\section{Fungal diseases of maize}

Stalk rot of Maize (Complex disease caused by bacterial and fungal pathogens) Downey mildew of Maize (Sclephthora sp and Pernospora sp.)

Leaf spot of Maize.

Zonate leaf spot (Gloeospora sorghi)

Grey Leaf Spot (Cercospora zeaemaydis).

Helminthosporium Leaf Spot.

Maydis leaf spot (Bipolaris maydis).

Turcicum leaf blight.

\section{Some major epidemics in case of maize}

Six major disease outbreaks have been recorded in India since 1960. Bacterial stalk rot appeared in the Tarai area of Uttar Pradesh in 1959 and in 1969 in Himachal Pradesh on hybrid Ganga 5, Brown stripe Downey mildew appeared in 1962 and 1964 in West Bengal, in 1954 in western Madhya Pradesh and South Eastern Gujarat in 1964 in North Bihar and in 1965 in Tarai region of Uttar Pradesh and parts of Himachal Pradesh. There was an outbreak of sorghum Downey Mildew in Rajasthan Karnataka and Tamil Nadu from 1960 to 1970. Turcicum leaf blight appeared in 1974 on hybrid Ganga 5, Deccan and Kisan in late 1968 outbreak of Banded leaf and sheath blight pathogen in Himachal Pradesh and other areas of Western Himalayas (Payak et. al., 1985).

Some of the important fungal diseases of maize are Southern Corn Leaf Blight (Bipolaris maydis) (SCLB), North corn leaf 
Blight (NCLB) commonly called as turcicum leaf blight and Grey Blight of Maize. NCLB is the most damaging leaf disease in maize, which can reduce the yield up to 50 per cent.

Turcicum leaf blight (TLB) or Northern Corn Leaf Blight (NCLB) is the most common endemic disease in maize. This name was used during the 1950s when this leaf blight became common in the United States. It is prevalent in the United States, Canada, India, Uganda, Kenya, Argentina, northern China, northern Spain and the United Kingdom. The causal agent of this disease is Exserohilum turcicum (pass.) Leonard and suggs. The pathogen is hemi-biotrophic in nature and penetrates the plant tissues through wounds and natural opening. Once the pathogen is inside the plant system after infection, its actions are more of necrotrophic in nature (Walsh et al., 2008). The optimum temperature required for the growth of the pathogen is 20 to $25^{\circ} \mathrm{C}$. Sporulation of the fungus is favored by high humidity and dew period (White, 2010). The telomorphic phase of this pathogen is Setosphaeria turcica which belongs to Ascomycota phylum. Since, the asexual stage of the pathogen is common the pathogen is always referred as Exserohilum turcicum. The fungus overwinters as chlamydospores or conidia on infected plant remains. Whenever there is dew in the atmosphere the spores become the first agent of disease development. The affected leaf has lesions initially spindle later spread to a major portion of the leaf (Fig 2). TLB is a foliar disease-causing severe yield loss. The range of yield loss due to NCLB is very high from 30 per cent to 90 per cent in susceptible hybrids. The severity of the disease greatly depends on the time of infection and climatic condition during the growth period of the crop.

Mueller et al., (2016) estimated corn yield loss in 22 corn-producing states of the United States from the year 2012 to 2015. This study showed that foliar diseases like northern corn leaf blight and grey leaf spot caused the largest yield loss. It was estimated that around 76.51 USD mean economic loss occurred per acre land. The intermittent showers in Karnataka during pre and post-harvest period of maize expose the crop to fungal infection (Janardhana et al., 1999).

Table.1 International grain Council's World Corn Projections (in million metric tonnes)

\begin{tabular}{|c|c|c|c|}
\hline & $\begin{array}{c}\mathbf{2 0 1 6 - 1 7} \\
\text { Estimated }\end{array}$ & $\begin{array}{c}\mathbf{2 0 1 7 - 1 8} \\
\text { Forecasted }\end{array}$ & $\begin{array}{c}\mathbf{2 0 1 8 - 1 9} \\
\text { Prediction }\end{array}$ \\
\hline Opening Stocks & 323.9 & 364.0 & 335.8 \\
\hline Production & 1131.1 & 1089.6 & 1109.0 \\
\hline Imports & 137.4 & 151.9 & 160.2 \\
\hline Total Availability & 1455.0 & 1453.6 & 1444.9 \\
\hline Food & 121.0 & 123.0 & 125.7 \\
\hline Industrial & 291.9 & 302.9 & 307.4 \\
\hline Feed & 635.5 & 654 & 674.5 \\
\hline Others & 42.6 & 37.9 & 39.8 \\
\hline Total Consumption & 1091.0 & 1117.8 & 1147.4 \\
\hline Exports & 137.4 & 151.9 & 160.2 \\
\hline Ending Stocks & 364.0 & 335.8 & 297.4 \\
\hline
\end{tabular}

Source: https://igc.int/en/default.aspx 
Table.2 International Grain Council's Indian corn Projections (in million metric tonnes)

\begin{tabular}{|l|l|l|l|}
\hline & $\begin{array}{l}\mathbf{2 0 1 6}-17 \\
\text { Estimated }\end{array}$ & $\begin{array}{l}\mathbf{2 0 1 7 - 1 8} \\
\text { Forecasted }\end{array}$ & $\begin{array}{l}\mathbf{2 0 1 8 - 1 9} \\
\text { Prediction }\end{array}$ \\
\hline Opening Stocks & 1.2 & 1.8 & 2.0 \\
\hline Production & 25.9 & 28.7 & 26.5 \\
\hline Imports & 0.1 & - & 0.1 \\
\hline Total Availability & 27.2 & 30.6 & 28.6 \\
\hline Food & 6.8 & 6.9 & 7.0 \\
\hline Feed & 12.4 & 14.7 & 14.1 \\
\hline Industrial & 4.5 & 4.7 & 4.8 \\
\hline Other & 1.1 & 1.3 & 1.2 \\
\hline Total Consumption & 24.9 & 27.6 & 27.1 \\
\hline Exports & 0.5 & 0.9 & 0.5 \\
\hline Ending Stocks & 1.8 & 2.0 & 1.1 \\
\hline & & & \\
\hline
\end{tabular}

Source: https://igc.int/en/default.aspx

Table.3 Disease scoring ranging from 1 to 5

\begin{tabular}{|c|l|}
\hline Rating & Description \\
\hline $\mathbf{1 . 0}$ & Very slight to slight infection, one or two to few scattered lesions on lower leaves. \\
\hline $\mathbf{2 . 0}$ & Light infection, a moderate number of lesions on lower leaves only \\
\hline $\mathbf{3 . 0}$ & Moderate infection, abundant lesions are on lower leaves, few on middle leaves. \\
\hline $\mathbf{4 . 0}$ & $\begin{array}{l}\text { Heavy infection, lesions are abundant on lower and middle leaves, extending to upper } \\
\text { leaves. }\end{array}$ \\
\hline $\mathbf{5 . 0}$ & $\begin{array}{l}\text { Very heavy infection, lesions abundant on almost all leaves, plants prematurely dry or } \\
\text { killed by the disease }\end{array}$ \\
\hline
\end{tabular}

Fig.1 Percentage of agriculture land by use in India

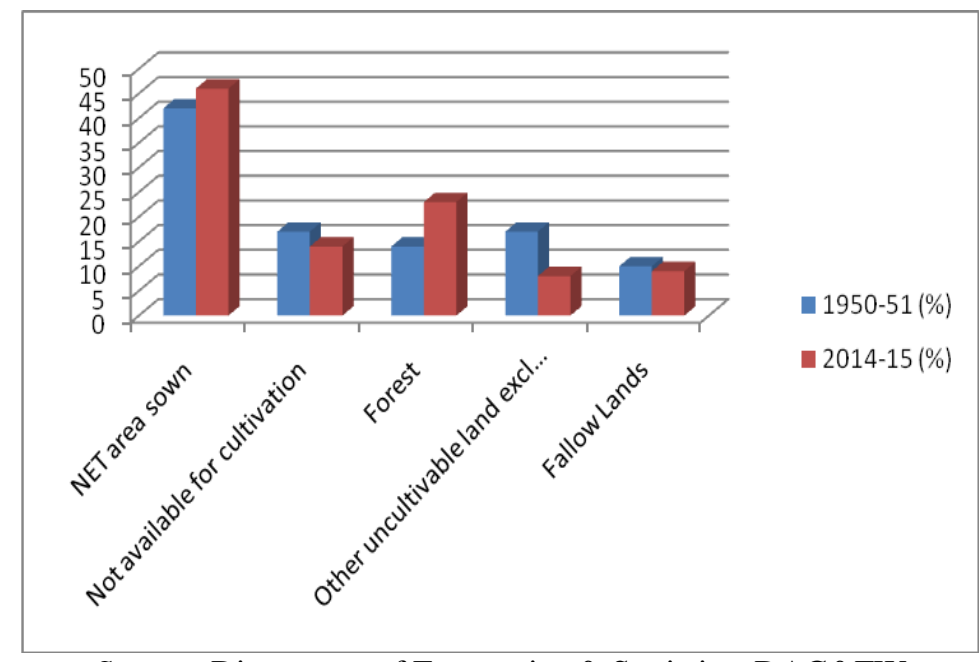

Source: Directorate of Economics \& Statistics, DAC\&FW 
Fig.2 Typical symptoms of Northern corn leaf blight on maize leaf

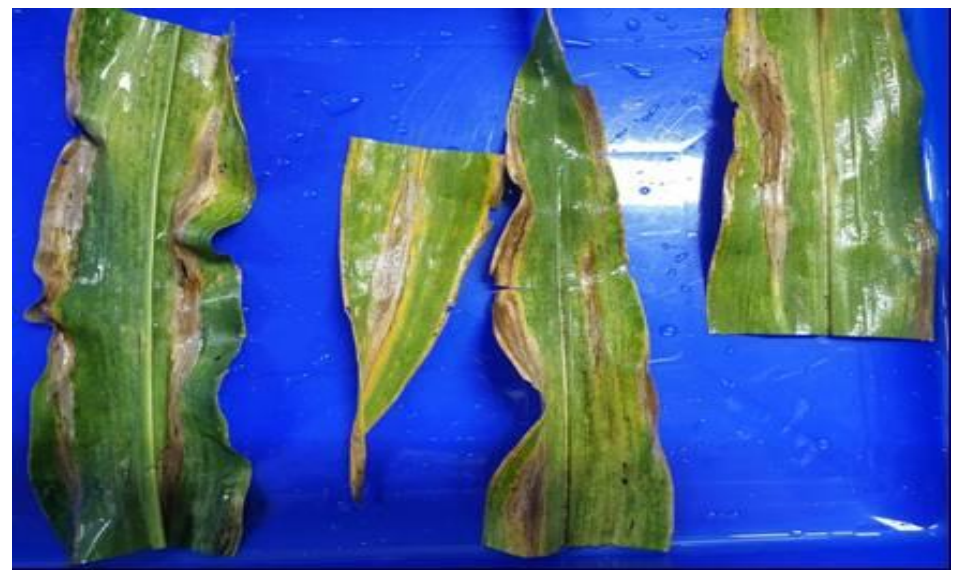

Fig.3 Chitinase activities specific at bond between $\mathrm{C}_{1}$ and $\mathrm{C}_{4}$ of the adjacent $\mathrm{N}$ acetylglucosamine

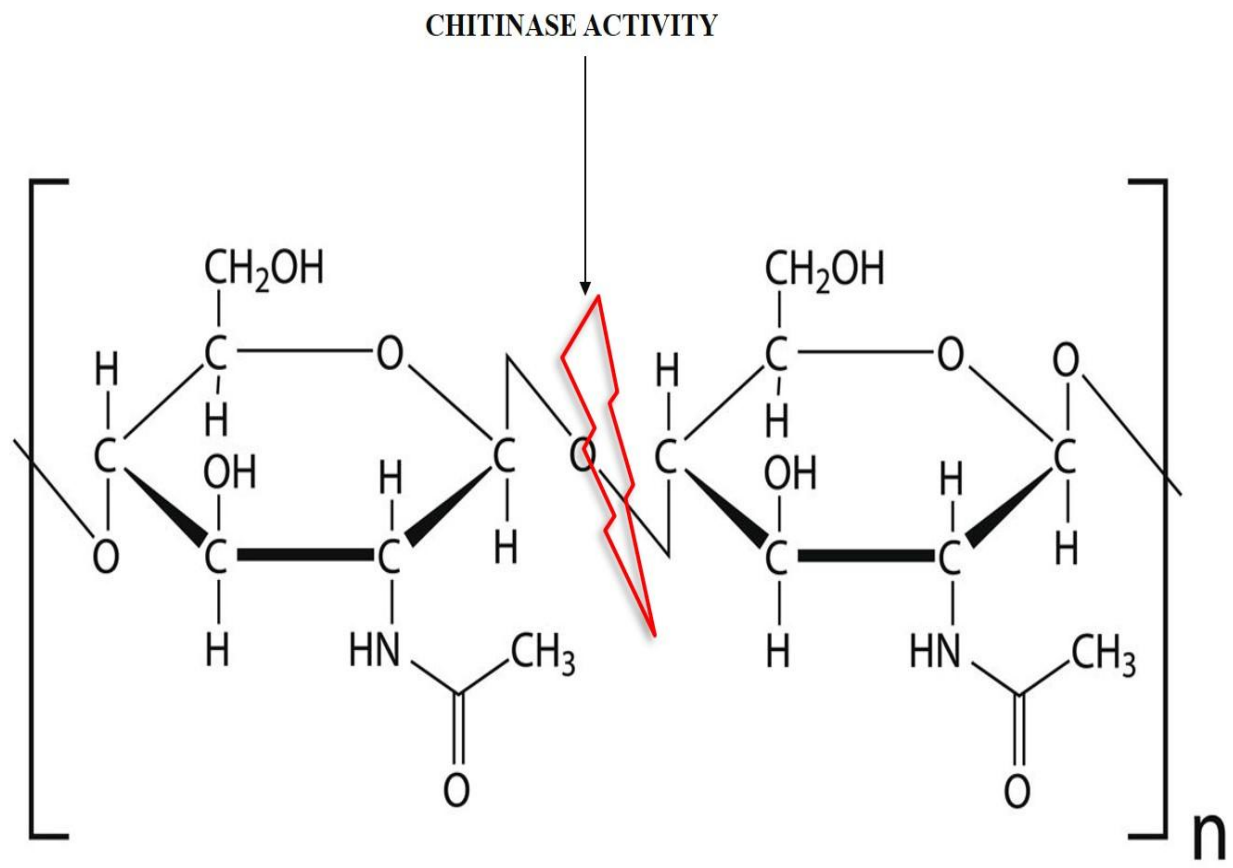

CHITIN

Vasanthkumar (1986) and Bhavanishankar et al., (1987) studied mycotoxins present in maize after harvesting at various places in Karnataka and found T-2 toxin, diacetoxyscirpenol, and zearalenone. Southern corn leaf blight caused by fungus Helminthosporium maydis is one of the major diseases. Vaibhav Singh and Yogenda Singh, (2014) reported about this disease and found that fungal diseases are limited by warmer climate and temperature. They observed that fungal diseases can cause significant yield losses from 9.7 per cent to 11.7 per cent in sub-tropic and temperate conditions. They 
claimed that the most economical way of controlling fungal diseases in maize is by developing resistant varieties. Common rust in maize is caused by biotrophic fungus Puccinia sorghi, a devastating foliar disease. This disease eventually leads to significant yield loss and increased input cost for the producer on chemical control. Being an obligate biotroph, this pathogen feeds on vegetative and reproductive parts of the plant (Sucher et al., 2017).

The chemical method to control TLB is the use of some fungicides like mancozeb (0.25per cent), carbendazim, and pyraclostrobin. Biocontrol agents like Trichoderma harzianum and Pseudomonas fluorescens are known to inhibit the pathogen and reduce the disease severity significantly (Vaibhav Singh and Yogenda Singh, 2014).

Unfortunately, chemical control does not guarantee complete protection having high cost-benefit ratio. Also, farmers must take a risk over health hazard, high cost to benefit ratio, soil pollution and lot more. Diversified climate country like India especially with more than ten agro-climatic zones it is good to go for multiple resistance to these diseases. There are few cultural practices to control the fungal diseases, but currently, resistant gene approach is the most eco-friendly and efficient method. This is the reason why plant scientist like biotechnologist, plant breeder, physiologists and plant pathologist contribution towards farming community becomes so important. There is a lot of hope and scope for a plant researcher today to develop resistant crop varieties which are more eco-friendly, durable and cheap in their protective action. Maize has a rich germplasm collection and wild species. These collections are a needful source for solutions to the biotic and abiotic stresses that the maize crop faces every day on the field.
Thus, the control of such pathogen becomes the at the most important need of the scientist. Use of chemical fungicides has already reached the threshold and farmers are seeking an eco-friendly substitute. Genetic engineering and development in transgenic technology give new hope for the farmers and scientist in disease control. Many resistant, PR protein genes can be manipulated to control fungal pathogens. Also, the idea of developing a transgenic line in maize must be supported with a proper callus induction and regeneration protocol using various explants. This article throws light on the antifungal PR proteins like glucanase and chitinase against NCLB, regeneration protocol in maize and screening of susceptible-resistant maize genotypes.

\section{Screening of maize lines against NCLB}

The most economical strategy to control turcicum leaf blight and a safe alternative are to look for plant genetic resistance. For this purpose, the screening of genotypes is very much necessary. Screening of the maize lines against NCLB is mainly done to know the level of resistance and susceptibility of maize lines to the pathogen. This involves isolation of the pathogen Exserohilum turcicum and its artificial inoculation on the lines to be tested. The lines can be screened based on the parameters like several days for incubationdisease development, percent of disease incidence and disease severity.

The type of growth media and temperature decides a success of the fungal isolation. Among the media tested, potato dextrose agar supported good growth of the fungus followed by maize leaf extract and potato carrot agar, while least growth was observed on Yeast with PDA medium with some exceptions. As the temperature increases from 20 to $25^{\circ} \mathrm{C}$ and 25 to $30^{\circ} \mathrm{C}$, there was an increase in the colony diameter of all the 
isolates on four tested media. There were significant differences in the growth of the fungus at different temperatures (Reddy et al., 2014). The optimum growth temperatures for most of the fungi studied was found to fall between $25^{\circ} \mathrm{C}$ to $30^{\circ} \mathrm{C}$ and above $40^{\circ} \mathrm{C}$ the growth was poor, and in some cases, mortality may occur. Misra and Singh, 1966 studied the effect of temperature and humidity on the development of a maize isolate of $\mathrm{H}$. turcicum and found that the optimum temperatures for spore germination, the growth of the fungus in culture, and for infection and development of disease were $20-30^{\circ} \mathrm{C}, 25-30^{\circ} \mathrm{C}$ and $30^{\circ} \mathrm{C}$ respectively.

Bhat et al., (2017) reported the artificial epiphytotic and screening of about seventytwo hybrids against NCLB. They have suggested that the possible way of improving resistance against TLB is through population improvement approach mainly by reciprocal recurrent selection. The disease score and percent disease incident were recorded at tasseling stage and 20 days after the tasseling stage. The turcicum fungus can affect maize at any stage of growth and development from the seedling stage to maturity stage. Thus, greenhouse screening of 10 maize lines was done against NCLB with the development of artificial epiphytotic condition (Mir et al., 2015). The maize lines classified as moderately resistant, resistant and susceptible. These screened lines can further be used by breeders for successfully developing genotypes of the desired level of resistance in disease-endemic areas for sustainable production.

The turcicum leaf blight disease incidence is also influenced by geographical locations. A prolonged screening work was done from 1999 to 2011 against TLB under the artificial epiphytotic condition at three different locations viz, Nagenahalli (Mandya), Almora and Varanasi which showed that the pathogen was more virulent in Mandya region compared to other climatic conditions (Vaibhav Singh and Yogenda Singh, 2014). The screening involved 118 maize genotypes. This experiment identified twenty-six resistant, fifty-six moderately resistant, twenty-six susceptible and ten highly susceptible maize genotypes. They used the same disease scoring technique given by Payak and Sharma (1983) ranging 1-5 (Table 3 ). The highly susceptible genotypes showed an average of 4.5 disease scoring.

Dutta et al., (2012) screened 26 elite maize inbred lines against all the three available races in India i.e. race2, race 3 and race 4. They were able to identify three lines resistant to all the three lines. Data from such research can be used to identify the source of resistant gene and help composite breeding in future. Recently, Yang et al., (2015) published a bioprotocol to screen maize genotypes for NCLB. It was a greenhouse seedling approach that is suitable for testing thousands of seedlings plant in a single experiment within duration of 37 days. Three scoring methods were used to quantify the disease severity: the area under disease progressive curve (AUDPC), the primary diseased leaf area of the inoculated leaf at 16 days post-inoculation (PrimDLA at $16 \mathrm{dpi}$ ) and the incubation period. By testing a diverse panel of maize genotypes, a high correlation between the three different methods was observed (81.9 per cent to 94.1 per cent), indicating that each of scoring methods can be applied for disease quantification. Thus, the seedling assay developed served as a relatively simple and high-throughput method for phenotyping NCLB disease resistance under greenhouse condition.

Gulzar et al., (2018) screened 36 early maturing varieties under field conditions. They have reported that out of 36 lines, twenty-seven lines were shown resistant and 
nine lines were moderately resistant against TLB. These resistant lines were further used to develop resistant high yielding varieties that can be grown in high altitude temperate agro-ecological conditions. Aflatoxins produced by fungus Aspergillus flavus is found to contaminate maize seeds which is detrimental for human food and feed safety.

Institute of Tropical Agriculture-Southern Regional Research Centre (IITA-SRRC) maize breeding collaboration for use in African National Programs and U.S. maize breeding programs screened six maize germplasm to find resistance against Aspergillus flavus. The result of these experiments showed that TZAR lines of IITA-SRRC have significantly lower toxin accumulation in the US environment. Resistance was demonstrated by the lines tested in 2010 and 2014 trials. In 2010, TZAR106 was among the lines with the lowest toxin accumulation, and in 2014, along with TZAR102, supported low aflatoxin. When evaluated as single cross hybrids in 2012, 2013 and 2014, several crosses involving IITA-SRRC lines accumulated low toxin. In 2012, TZAR103xHBA1 was one of 4 lines with the lowest concentration of aflatoxin. In 2014, five IITA-SRRC hybrids were among the lowest with TZAR102xVa35 and TZAR102xLH132 being the two lowest (Brown et al., 2016).

In the Bihar region, the full season maturity group of maize varieties had a serious problem of maydis leaf blight caused by Helminthosporium maydis. To find resistance against this disease, screening was done under the artificial epiphytotic condition for 51 maize inbred lines of full-season maturity group. "Significant variability in the severity of this disease was observed among genotypes. The per cent disease severity ranged 1.5-4.5 at leaf stage. Out of 51 genotypes, it was rated as 26 resistant, 8 moderately resistant, 13 moderately susceptible, 2 susceptible and 2 highly susceptible against maydis leaf blight (Kumar et al., 2018). The technique of scoring diseases to important diseases was published in 1983. Payak and Sharma in 1983 gave disease scoring for turcicum leaf blight. The scoring was from 1 to 5 (Table.3).

\section{Antifungal PR (Pathogenesis-Related) proteins against major diseases in maize:}

\section{Screening for resistance genes / antifungal genes}

Screening for resistant genes with the aid of molecular techniques is a vital process in a breeding program. Duan et al., (2019) studied the genes responsible for resistance against Pythium stalk rot in maize. They predicted that climate change, cultivation practices and monocropping of hybrids made the stalk rot a major disease in recent years. This disease can strikingly affect susceptible maize lines under high humid conditions. Multiple kinds of Downey mildew are recorded in maize. It is one of the major diseases in maize causing significant economic loss. It is more common in tropical parts of Asia. Yield loss; due to Downey mildew up to 70 per cent have been documented in India. Sumathi et al., (2018) identified the best performing progenies of resistant lines against sorghum downey mildew based on their biometric performance. It is recommended to identify the source of resistance specific to the pathogen to mitigate this disease. Plant biotechnology is one of a kind technique which allows the scientists to develop plant varieties with desired traits to tackle fungal diseases or any other plant stress for that matter. This has enabled the breeder to develop crop varieties that were not possible by conventional breeding. Genetically modified crops in India still have a long way to go, currently cotton is the only crop plant permitted by the government. 
There are several biosafety frameworks in India to patrol the activities related to GMO. But biotechnology offers other techniques like molecular markers, gene sequencing and metabolomics to help the plant breeders (Reddy and Zehr, 2004).

\section{Chitinase and Glucanase PR proteins in maize against NCLB}

Higher plants have a broad range of mechanisms to protect themselves against various threats including physical, chemical and biological stresses, such as wounding, exposures to salinity, drought, cold, heavy metals, air pollutants, and ultraviolet rays and pathogen attacks, like fungi, bacteria, and viruses (Agrios G N). Plants have developed various mechanisms to defend these stresses among this expression of PR proteins in very important. PR proteins were first discovered in tobacco plants while studying tobacco mosaic virus.

Van Loon (1997) reported that pathogen related (PR) proteins play an important role in plant defense against maize. Chitinase is one of the major subgroup of PR proteins. Chitin is the main component of the fungal cell wall. Chitinase has the enzyme activity to break down the bond between $\mathrm{C}_{1}$ and $\mathrm{C}_{4}$ of the adjacent $\mathrm{N}$-acetylglucosamine, which is the building block of the chitin (Fig 3). This results in disruption of fungal cells and ultimately leads to the death of the pathogen. Chitinolytic enzymes belong to four recognized families of PR proteins (PR-3, PR4, PR-8, and PR-11) that respond to attack by potential pathogens or the presence of elicitor treatments and a variety of abiotic stresses (Van Loon et al., 2006). Seven chitinase genes were identified that had alleles associated with increased resistance to aflatoxin accumulation and $A$. flavus infection in field-grown maize, these alleles were done by QTL mapping and GWAS (Genome-wide association studies). Both exo-beta -1,3glucanases and endo-beta-D-glucanase have been found in maize (Jondle et al., 1989). Beta-1-3-glucanase is involved in polysaccharide modification and degradation in maize plants. Glucanase enzyme activity on various isogenic resistant lines of maize was studied by inoculating with Exserohilum turcicum. It was found that the enzyme activity increased with increased inoculation and maximum glucanase activity found after 14 days of infection.

Synthesis of PR proteins is induced by infection of the pathogen. Fusarium moniliforme infects maize seedlings. Cordero et al., (1992) infected this pathogen to maize seedlings to isolate to acid-soluble antifungal proteins. They were found to have both acidic and basic properties. Non-denaturing electrophoresis showed the apparent size of the proteins to a size of 23 and $24 \mathrm{kDa}$. The serological studies of these proteins showed them similarity with tobacco PR-1a protein. Not just the fungal infection but wounding in maize plants has also reported accumulation of RNA encoding chitinase class II and class I. The full cDNA sequence of these proteins isolated from wounded plants showed similarity with the nucleotide sequence of pathogenesis-related protein family fours (PR-4). Chitinase belongs to PR family four under the classification based on chemical structure and functions. In-situ mRNA hybridization showed ZmPR4 mRNA the embryo that was in contact with the fungus had more expression of such a gene. The same trend was observed in wounded seedlings and treatment with abscisic acid or methyl jasmonate. This was considered as the first layer of defense response in maize plants (Bravo et al., 2003). The food allergin is considered specific to their physical structure and mode of action. The plant chitinase is considered to be an allergin. Thus, a recombinant chitinase rChiA protein of maize 
origin was extracted from Pichia pastoris by differential precipitation and cation exchange chromatography. Enzyme activity and modelling were done for this protein and allergenicity was analyzed by immunoblot assay. This study reported by Volpicella et al., (2017) showed that chitinase is actively involved in the hydrolysis of glycol chitin and tetra-N-acetylchitotetraose. In-vitro analysis of the enzyme showed that the maximum activity of the enzyme is at $\mathrm{pH} 3.0$ and at the temperature of $70^{\circ} \mathrm{C}$.

Plant chitinase belongs to a glycoside hydrolase family 19, plant class IV. ChitA a Zea mays chitinase enzyme consists of hevein like domain attached to C-terminal. A study by Chaudet et al., (2014) in-ear rot affected maize plant showed that this hevein like domain doesn't have any role in enzymatic activity. Fungal protease cleaves even like the domain to form truncated chitinase (ChitA protein). This mutant form was expressed and purified. The study gave similar action as a full-length enzyme. Naumann and Wickrow (2010) for the first time reported that the fungal targeted plant chitinase in maize varies among different inbred lines. They studied the role of ChitA protein in combating Stenocarpella maydis which causes dry-ear and stalk rot of maize. B73 genotype was found to express an alloform of chitinase, ChitA-F which was susceptible to Stenocarpella maydis. Whereas new allele identified in LH82 genotype produced ChitA$\mathrm{S}$ protein which is resistant to $S$. maydis. Rhizoctonia root rot caused by Rhizoctonia solani is a major disease in maize. Medicinal plant extracts have been found to trigger antifungal genes in maize as a non-chemical method of disease control. The methanol extract of five such plants namely Eucalyptus tereticornis Sm., Ammi visnaga (L.) Lam., Azadirachta indica, Rheum Palmatum L. and Adansonia digitata L. were extracted and treated on maize plants. These extracts proved to have an antifungal activity to some extent.
Out of the 69 compounds analyzed through gas chromatography fatty acids and coumarin compounds were found to possess antifungal properties (Rashad et al., 2018). Further, when they observed up-regulated genes in treated maize plants, most of the genes were found to be defense-related like S-domain class receptor-like kinase 3 and glutathione-Stransferase1. There was an about 2.36-fold increase in the expression of PR protein chitinase when analyzed in real-time PCR. Two chitinase proteins were extracted from maize seeds, ChitA and ChitB, both had a mass of around $28-\mathrm{kDa}$. The sequence of protein shared 87 per cent homology with each other. But the biochemical and in-vitro antifungal activity analysis showed a notable difference. According to their study, ChitA had a better antifungal property and up to three-fold higher specific activity compared to ChitB. It was observed that the binding constant $(\mathrm{Kd})$ was about 10-fold lower in ChitA compared to ChitB, thus two enzymes differing in binding ability with the substrate. This steady thrown light on the diversity of chitinase enzymes present in the maize genome (Huynh et al., 1992).

\section{Synergistic effect of chitinase and $\beta-1,3$ -} glucanase in transgenic plants

Chitinase genes, alone or together with $\beta-1,3-$ glucanase genes, have been transferred to several plant species, expressed and those effects were studied. In most cases, the resulting transgenic plants exhibit enhanced levels of fungal disease resistance or delayed symptom development as compared to the control plants (Zhu et al., 1994). But several studies have shown that plants transformed with chitinase or $\beta$-1, 3-glucanase gene alone did not exhibit resistance to certain pathogens or showed less resistance compared to plants which were transformed with both the $\beta-1,3-$ glucanase, and chitinase genes. Like $\beta-1,3-$ glucanase, chitinases inhibit only a limited number of fungal species, therefore, these two 
enzymes have a synergistic effect. Plant chitinases alone usually affect only the hyphal tip and are unable to effectively degrade harder chitin structures of fungi. But whenever these two enzymes are combined, a synergic effect can usually be observed. For example, tomato plants expressing tobacco class I $\beta$-1,3-glucanase and chitinase transgenes showed increased tolerance to infection by Fusarium oxysporum f.sp. lycopersici (Jongedijk et al., 1995). Also, in tobacco plants transformed with a barley class II basic $\beta$-1, 3-glucanase along with a barley class II basic chitinase gene showed enhanced levels of protection against Rhizoctonia solani as compared to plants transformed with a single gene (Jach et al., 1995).

Bioinformatics is an indispensable tool in our research today. Screening techniques can also be integrated with certain computational tools and algorithms.

Earlier construction of a decision tree based on clustering and researches was used as a bioinformatics tool to screen several maize genotypes. Wang and Zhang (2006) introduced a new decision tree algorithm. In this tool, parameters like leaf area, plant height, dry weight, potassium intake, and others were considered. This tool gave more improved performance in the construction of the decision tree and accurate screening.

\section{Semi-quantitative RT-PCR to study relative gene expression ( $\mathrm{mRNA}$ levels)}

Semi-quantitative reverse transcription PCR is a preliminary technique to study the relative expression of gene-based on band intensity. This technique involves isolation of mRNA and cDNA synthesis. Further, this cDNA is used to amplify the gene of interest and the PCR product is run over agarose gel electrophoresis.
The banding intensity is determined by various image software and the mRNA levels can be quantified. The relative expression can be calculated by normalizing the banding intensity with any housekeeping. However, this is a preliminary technique; further qRTPCR should be done for publications.

Semi-quantitative real-time RT-PCR involves multiple individual steps (Walker et al., 2003). These include:

(1) Preparation of RNA

(2) First strand DNA synthesis (cDNA production)

(3) Optimization of reaction conditions (primer concentration, TMS, etc.)

(4) The kinetic PCR; and

(5) Data analysis.

Semi-quantitative RT-PCR can be used for tissue-specific expression levels. It was used to determine the levels of rice aquaporins genes in leaf blade, roots, and anthers. The intensity of the bands were quantified and normalized for relative expression. Also, the technique was used at different stages of growth like early flowering, early tillering and panicle formation stages (Sakurai et al., 2005). Semiquantitative RT-PCR analysis can be used to assess the expression levels of multiple transcripts from the same sample (Marone et al., 2001).

Semi-quantitative RT PCR can be used to study both temporal and special expression of the target gene. In rice, starch synthase (EC 2.4.1.21) is important for grain filling and quality. The expression of this gene is different parts of rice grain at different stages of development was done through the technique of semi qRT-PCR. Starch synthase can be classified into starch synthase I (SSI), SSII, SSIII, SSIV and granule-bound starch synthase (GBSS). Through sequence analysis, it was found that rice has two genes each for 
SSIII, IV, and GBSS. One gene for SSIII and three for SSII. Temporal expression profile of these genes were done and genes were classified into three groups "(i) early expressers (SSII-2, III-1, GBSSII), which are expressed in the early stage of grain filling; (ii) late expressers (SSII-3, III-2, GBSSI), which are expressed in the mid to later stage of grain filling; and (iii) steady expressers (SSI, II-1, IV-1, IV-2), which are expressed relatively constantly during grain filling" (Hirose and Terao, 2004).

Expression studies in simple terms involve quantification of mRNA in the sample which was present at the time of sample collection. To compare the expression of different genes normalization of the total RNA content is important.

A very small amount of RNA in the sample also poses a problem in the efficiency of RTPCR. RNA instability makes it problematic for research to use the external standard for normalization. Thus, to avoid all these problems, selection of appropriate internal control genes whose expression is constant in all tissues is required (Brunner et al., 2004). COR gene (Wcor14) in wheat is a coldresponsive gene which helps the plants to withstand cold or freezing conditions in temperate areas. Expression of this gene was studied by adopting semi qRT-PCR in Iranian germplasms of wheat. It was found that the gene is induced early (within 3-6 hours) of exposure to the cold temperature of 4 degree Celsius (Ganeshan et al., 2009).

Semi-quantitative RT-PCR requires an equal concentration of cDNA used in PCR to study the gene expression. Also, the number of cycles of PCR to be done had to be standardized such that the total content of cDNA does not reach a plateau. These two factors make sure that the PCR reaction was stopped at rapid amplification phase so that there should not be competition between two primers. This facilitates to compare the band intensity (density) to study gene expression. Abdel et al., (2016) standardized the number of PCR cycles to 30. They studied the expression pattern of the dehydrin gene in wheat. They equalized the cDNA concentration to $200 \mathrm{ng}$. Similar expression studies were done in the mRNAs of $\mathrm{H}^{+}$ATPase genes present in the plasma membrane. This study was conducted in root cells of cucumber grown in normal and iron deficit conditions in the soil. The whole idea was to determine the expression of two such $\mathrm{H}^{+}$-ATPase genes in cucumber." cDNAs (CsHA1 and CsHA2) were isolated from cucumber and their expression analyzed". Partial cDNA of these two genes were synthesized and 3' RACE method was adopted to amplify the cDNA (Santi et al., 2005).

Thus, Morphological and molecular screening methods helps in identification of major resistant genotypes against northern / turcicum leaf blight of maize.

The molecular screening methods further helps in isolation, cloning and transformation of two or more antifungal genes into maize against northern leaf blight using gene pyramiding techniques. Gene pyramiding techniques involves the combining of more than one gene under the control of different promoters to enhance their expression in maize.

\section{Acknowledgment}

The authors are thankful to DST-SERB, Department of Science and Technology, Government of India for providing financial assistance for carrying the project entitled "Multigene approach for the control of fungal disease Turcicum Leaf Blight of Maize (Zea mays)" vide File no. EEQ/2017/000436 dated 04/09/20182. 


\section{References}

Abdel-Tawab, F. M., Abo-Doma, A., and Edris, S., 2016, Semi-quantitative RTPCR analysis for dehydrin gene expression levels in wheat under drought stress. Egypt J. of Genet Cytol., 37(1): 95-102.

Ahuja, I., De Vos, R.C., and Bones, A.M. (2010), Plant molecular stress responses face climate change. Trends Plant Sci., 15: 664-674.

Anonymous, 2017, India Maize Summit, 2017-18.

Basu, S.K., Dutta, M., and Goyal, A., 2010, Is genetically modified crop the answer for the next green revolution? GM Crops., 1: 68-79.

Bhat, J. S., Mukri, G., and Patil, B. S., 2017, Turcicum Leaf Blight Resistance in Maize: Field Screening of New Inbreds and Hybrids. Ecol. and Environ., 32 (1): 22-26.

Bhavanishankar, Thimmappaiah, N., and Thimmappaji Shantha, 1987, Natural occurrence of Fusarium toxins in peanut, sorghum and maize from Mysore (India). J. Sci. Food Agric., 40:327-332.

Bravo, J. M., Campo, S., Murillo, I., COCA, M., and San Segundo, B., 2003, Fungus-and wound-induced accumulation of mRNA containing a class II chitinase of the pathogenesisrelated protein 4 (PR-4) family of maize. Plant Mol Bol., 52(4): 745-759.

Brown, R., Williams, W., Windham, G., Menkir, A. and Chen, Z. Y., 2016, Evaluation of African-bred maize germplasm lines for resistance to aflatoxin accumulation. Agron. 6(2): 24.

Brunner, A. M., Yakovlev, I. A. and Strauss, S. H., 2004, validating internal controls for quantitative plant gene expression studies. BMC Plant Boil.
4(1): 14

Chaudet, M. M., Naumann, T. A., Price, N. P. and Rose, D. R., 2014, Crystallographic structure of ChitA, a glycoside hydrolase family 19, plant class IV chitinase from Zea mays. Protein Sci., 23(5): 586-593.

Cordero, M. J., Raventos, D., and San Segundo, B., 1992, Induction of PR proteins in germinating maize seeds infected with the fungus Fusarium moniliforme. Physiol. Mol. Plant Pathol. 41(3): 189-200.

Duan, C., Song, F., Sun, S., Guo, C., Zhu, Z. and Wang, X., 2019, Characterization and molecular mapping of two novel genes resistant to Pythium stalk rot in maize. Phytopathol. 109(5): 804-809.

Dutta, R., Shekhar, M., \& Lal, S., 2012, Evaluation of maize genotypes for locating sources of resistance to Exserohilum turcicum, incitant of turcicum leaf blight of maize. Indian Phytopathol.58 (1):552-554

Ganeshan, S., Denesik, T., Fowler, D. B. and Chibbar, R. N., 2009, Quantitative expression analysis of selected low temperature-induced genes in autumnseeded wheat (Triticum aestivum L.) reflects changes in soil temperature. Environ Exper. Bot., 66(1): 46-53.

Gulzar, S., Dar, Z. A., Ahangar, M. A., Lone, A. A., Bhat, M. A., Kamal-UD-Din, M. A. and Majid, A., 2018, Identification of reaction pattern to turcicum leaf blight among early maturing maize (Zea mays L.) inbred lines. J. Pharmacogn. Phytochem. 7(1): 1657.

Hirose, T. and Terao, T., 2004, A comprehensive expression analysis of the starch synthase gene family in rice (Oryza sativa L.). Planta, 220(1): 916.

Huynh, Q. K., Hironaka, C. M., Levine, E. B., Smith, C. E., Borgmeyer, J. R. and 
Shah, D. M, 1992, Antifungal proteins from plants. Purification, molecular cloning, and antifungal properties of chitinases from maize seed. J Biol. Chem., 267(10): 6635-6640.

Jach, G., Görnhardt, B., Mundy, J., Logemann, J., Pinsdorf, E., Leah, R., and Maas, C., 1995, Enhanced quantitative resistance against fungal disease by combinatorial expression of different barley antifungal proteins in transgenic tobacco. The Plant Journal, 8(1): 97-109.

Janardhana, G.R., Raveesha, K.A. and Shetty, H.S., 1999, Mycotoxins contamination of maize grains grown in India (Karnataka). Food Chem. Toxicol. 37 (8): 863-868.

Ji, W., Hen, H., and Zhao, S., 2010, Identification of physiological races of Setosphaeria turcica in northeast corn region of Heilongjiang. J. Maize Sci., 18:128-130.

Jondle, D. J., Coors, J. G., \& Duke, S. H., 1989, Maize leaf $\beta$-1, 3-glucanase activity in relation to resistance to Exserohilum turcicum. Can. J. Bot., 67(1):263-266.

Jongedijk, E., Tigelaar, H., Van Roekel, J. S., Bres-Vloemans, S. A., Dekker, I., Van Den Elzen, P. J., and Melchers, L. S., 1995, Synergistic activity of chitinases and $\beta$-1, 3-glucanases enhances fungal resistance in transgenic tomato plants. Euphytica, 85(1-3):173-180.

Kumar, C., Chand, P., Akhtar, N. S., Choudhary, C. S., and Keshari, N., 2018, Screening of maize genotypes under different maturity group against maydis leaf blight disease of maize Caused by Helminthosporium maydis. Current J. Applied Sci.Tech.,:1-7.

Li, Y., Guan, K., Schnitkey, G. D., Delucia, E., and Peng, B., 2019, Excessive rainfall leads to maize yield loss of a comparable magnitude to extreme drought in the United States. Global change biology, 25(7): 2325-2337.

Marone, M., Mozzetti, S., De Ritis, D., Pierelli, L. and Scambia, G., 2001, Semi quantitative RT-PCR analysis to assess the expression levels of multiple transcripts from the same sample. Biological Procedures Online, 3(1): 19.

Mir, S. D., Ahmad, M., Parray, G. A., and Razvi, S. M., 2015, Screening of maize inbred lines under artificial epiphytotic conditions for Turcicum leaf blight (Exserohilum turcicum). Afr. J. Microbiol. Res., 9(7):481-483

Misra, A. P., and Munankami, M. B., 1966, Helminthosporium tetramera McKinney causing foot root of wheat at Sebour. In Plant Disease Problems. Proceedings of the First International Symposium on Plant Pathology, Indian Phytopath. Soc, IARI, New Delhi.

Mueller, D. S., Wise, K. A., Sisson, A. J., Allen, T. W., Bergstrom, G. C., Bosley, D. B., and Collins, A., 2016, Corn yield loss estimates due to diseases in the United States and Ontario, Canada from 2012 to 2015. Plant Health Progress, 17(3): 211222.

Naumann, T. A. and Wicklow, D. T., 2010, Allozyme-specific modification of a maize seed chitinase by a protein secreted by the fungal pathogen Stenocarpella maydis. Phytopatholog. 100(7): 645-654.

Payak, M. M. and Sharma, R. C., 1983, Disease rating scales in maize in India. Techniques of scoring for resistance to important diseases of maize, All India Coordinated Maize Improvement Project, Indian Agricultural Research Institute, New Delhi, 1-4.

Rashad, Y. M., Aseel, D. G. and Hafez, E. E., 2018, Antifungal potential and defense 
gene induction in maize against Rhizoctonia root rot by seed extract of Ammi visnaga (L.) Lam. Phytopathol Mediterr., 57(1): 73-88

Reddy, K. V. S. and Zehr, U. B., 2004, Novel strategies for overcoming pests and diseases in India. New Directions for a Diverse Planet, Proceedings of 4th Intl. Crop Science, Brisbane, Australia, 26.

Reddy, T. R., Reddy, P. N., Reddy, R. R., and Reddy, S. S., 2014, Effect of different media and temperature on the growth of the Exserohilum turcicum incitant of turcicum leaf blight in maize. Environment and Ecology, 32(1): 2226.

Sakurai, J., Ishikawa, F., Yamaguchi, T., Uemura, M., and Maeshima, M., 2005, Identification of 33 rice aquaporin genes and analysis of their expression and function. Plant and Cell Physiology, 46(9):1568-1577.

Santi, S., Cesco, S., Varanini, Z. and Pinton, R., 2005, Two plasma membrane H+ATPase genes are differentially expressed in iron-deficient cucumber plants. Plant Physiol. Biochem., 43(3):287-292

Shelden, M.C., and Roessner, U., 2013, Advances in functional genomics for investigating salinity stress tolerance mechanisms in cereals. Front Plant Sci., 4:123.

Sucher, J., Boni, R., Yang, P., Rogowsky, P., Büchner, H., Kastner, C. and Keller, B., 2017, The durable wheat disease resistance gene Lr34 confers common rust and northern corn leaf blight resistance in maize. Plant Biotechnol. J. 15(4):489-496.

Sumathi, K., Ganesan, K. N., and Senthil, N., 2018, Studies on Frequency Distribution of Sorghum Downy Mildew Resistant BC2F1 Progenies in Maize. Int. J. Curr. Microbiol. App.
Sci, 7(6): 3621-3628.

Vaibhav Singh and Yogenda Singh, 2014, Evaluation of Trichoderma harzianum and Pseudomonas fluorescens isolates for their antagonistic potential against Exserohilum turcicum causing leaf blight of sorghum. The Bioscan, 9(3): 1171-1175.

Van Loon, L. C., 1997, Induced resistance in plants and the role of pathogenesisrelated proteins. European J. of plant patholo., 103(9):753-765.

Van Loon, L. C., Rep, M., \& Pieterse, C. M., 2006, Significance of inducible defense-related proteins in infected plants. Annu. Rev. Phytopathol., 44:135-162.

Vasanthkumar. 1986, Studies on some seedborne fungal diseases of maize in Karnataka. Ph.D. Thesis. University of Mysore, India.

Volpicella, M., Leoni, C., Fanizza, I., DISTASO, M., LEONI, G., FARIOLI, L. AND CECI, L. R., 2017, Characterization of maize chitinase-A, a tough allergenic molecule. Allergy, 72(9):1423-1429.

Walker, S. J., Worst, T. J., and Vrana, K. E., 2003, Semiquantitative real-time PCR for analysis of mRNA levels. In Drugs of Abuse. Humana Press. Pp. 211-227.

Wang, B., and Zhang, H., 2006, Improving the ranking performance of decision trees. In European Conference on Machine Learning, Springer, Berlin, Heidelberg, 461-472.

white, D.G., 2010, Compendium of Corn Diseases. 3rd ed. APS Press, St. Paul, MN.

Yang, P., Herren, G., Krattinger, S. G., and Keller, B., 2015, Large-scale Maize Seedling Infection with Exserohilum turcicum in the Greenhouse. Proceedings of the National Academy of Sciences of the United States of America. 
Zaidi, P.H, Maniselvan, P., and SRIVASTAVA, A., 2010, Genetic analysis of water logging tolerance in tropical maize (Zea mays L.). Maydica, 55:17-26.

Zhu, Q., Maher, E. A., Masoud, S., Dixon, R.

A., and Lamb, C. J., 1994, Enhanced protection against fungal attack by constitutive co-expression of chitinase and glucanase genes in transgenic tobacco. Nature Biotechnology, 12(8): 807.

\section{How to cite this article:}

Nagesha, N. and Adarsh, D. P. 2020. An Overview of Morphological and Molecular Screening of Antifungal Genes against Northern Corn Leaf Blight (Exserohilum turcicum) from Maize Genotypes-A Review. Int.J.Curr.Microbiol.App.Sci. 9(02): 109-125. doi: https://doi.org/10.20546/ijcmas.2020.902.014 